\title{
Karyotype and Idiogram of Indian Hog Deer (Hyelaphus porcinus) by Conventional Staining, GTG-, High-Resolution and Ag-NOR Banding Techniques
}

\author{
Krit Pinthong ${ }^{1}$, Alongklod Tanomtong ${ }^{2 *}$, Hathaipat Khongcharoensuk ${ }^{2}$, \\ Somkid Chaiphech ${ }^{3}$, Sukjai Rattanayuvakorn ${ }^{4}$ and Praween Supanuam ${ }^{5}$ \\ ${ }^{1}$ Department of Fundamental Science, Faculty of Science and Technology, Surindra Rajabhat University, Surin, \\ Muang 32000, Thailand \\ ${ }^{2}$ Toxic Substances in Livestock and Aquatic Animals Research Group, Department of Biology, Faculty of Science, \\ Khon Kaen University, Khon Kaen, Muang 40002, Thailand \\ ${ }^{3}$ Department of Animal Science, Rajamangala University of Technology Srivijaya Nakhonsrithammarat Campus, \\ Nakhonsrithammarat, Thungyai 80240, Thailand \\ ${ }^{4}$ Department of Science and Mathematics, Faculty of Agriculture and Technology, Rajamangala University of \\ Technology Isan, Surin Campus, Surin, Muang 32000, Thailand \\ ${ }^{5}$ Biology Program, Faculty of Science, Ubon Ratchathani Rajabhat University, Ubon Ratchathani, Muang 34000, \\ Thailand
}

Received April 19, 2016; accepted January 20, 2017

\begin{abstract}
Summary Standardized karyotype and idiogram of Indian hog deer (Hyelaphus porcinus) at Khon Kaen Zoo, Thailand was explored. Blood samples were taken from two male and two female deer. After standard whole blood T-lymphocytes were cultured at $37^{\circ} \mathrm{C}$ for $72 \mathrm{~h}$ in presence of colchicine, metaphase spreads were performed on microscopic slides and air-dried. Conventional staining, GTG-, high-resolution and Ag-NOR banding techniques were applied to stain the chromosome. The results show that the diploid chromosome number of $H$. porcinus was $2 n=68$, the fundamental number (NF) was 70 in both males and females. The types of autosomes observed were 6 large telocentric, 18 medium telocentric and 42 small telocentric chromosomes. The X chromosome was large metacentric chromosome and Y chromosome was small submetacentric chromosome. The GTGbanding and high-resolution techniques showed that the numbers of bands and locations in H. porcinus are 239 and 301, respectively, and each chromosome pair could be clearly differentiated. In addition, the subtelomeric q-arm of chromosome pairs 1 and 2 showed clearly observable nucleolar organizer regions (NORs). Our results are the first reports of GTG-, high-resolution and Ag-NOR banding techniques on this species. The karyotype formula of $H$. porcinus is as follows:
\end{abstract}

$$
2 n(68)=\mathrm{L}_{6}^{\mathrm{t}}+\mathrm{M}_{18}^{\mathrm{t}}+\mathrm{S}_{42}^{\mathrm{t}}+\text { Sex-chromosomes }
$$

Key words Hyelaphus porcinus, Karyotype, GTG banding, Ag-NOR banding.

Deer are the ruminant mammals forming the family Cervidae. The deer family has at least 90 species; the list is based on several molecular and phylogenetic studies. The family Cervidae is organized as two subfamilies, Cervinae (old world deer) and Capreolinae (new world deer). The Cervidae is divided into two tribes, Muntiacini (muntjac) and Cervini (true deer). The Cervini consist of eight genera including Dama, Axis, Rucervus, Cervus, Panolia, Elaphurus, Hyelaphus and Rusa. The genus Hyelaphus includes four species, Indian hog deer (H. porcinus), Indochinese hog deer (H. annamiticus), Calamian deer (H. calamianensis) and Bawean deer $(H$. kuhlii) (Meijaard and Groves 2004, Pitra et al. 2004).

\footnotetext{
*Corresponding author, e-mail: tanomtong@hotmail.com DOI: $10.1508 /$ cytologia. 82.227
}

The extant deer species have diverse karyotypes; their diploid chromosome numbers range from $2 n=6$ in the female Indian muntjac (Muntiacus muntjak vaginalis) to $2 n=80$ in the Siberian roe deer (Capreolus capreolus pygargus) (Wurster and Benirschke 1970, Neitzel 1987, Tanomtong et al. 2005, Huang et al. 2005, Tanomtong et al. 2010, Khongcharoensuk et al. 2017).

The Indian hog deer is a small deer whose habitat ranges from Pakistan, through northern India, to mainland Southeast Asia, which inhabits much of Pakistan, Northern India, Nepal, Bangladesh, and Southwestern Yunnan (China); introduced populations also exist in Australia, the United States and Sri Lanka. The Indian hog deer's coat is quite thick and generally a uniform dark-brown in winter except for the underparts of the body and legs which are lighter in colour. During late 
spring, the change to a summer coat of rich reddish brown commences, although this may vary between individuals. Many hog deer show a dark dorsal stripe extending from the head down the back of the neck and along the spine. In summer, there is usually a uniform row of light-coloured spots along either side of the dorsal stripe from the shoulders to the rump. The tail is fairly short and brown but tipped with white. The underside
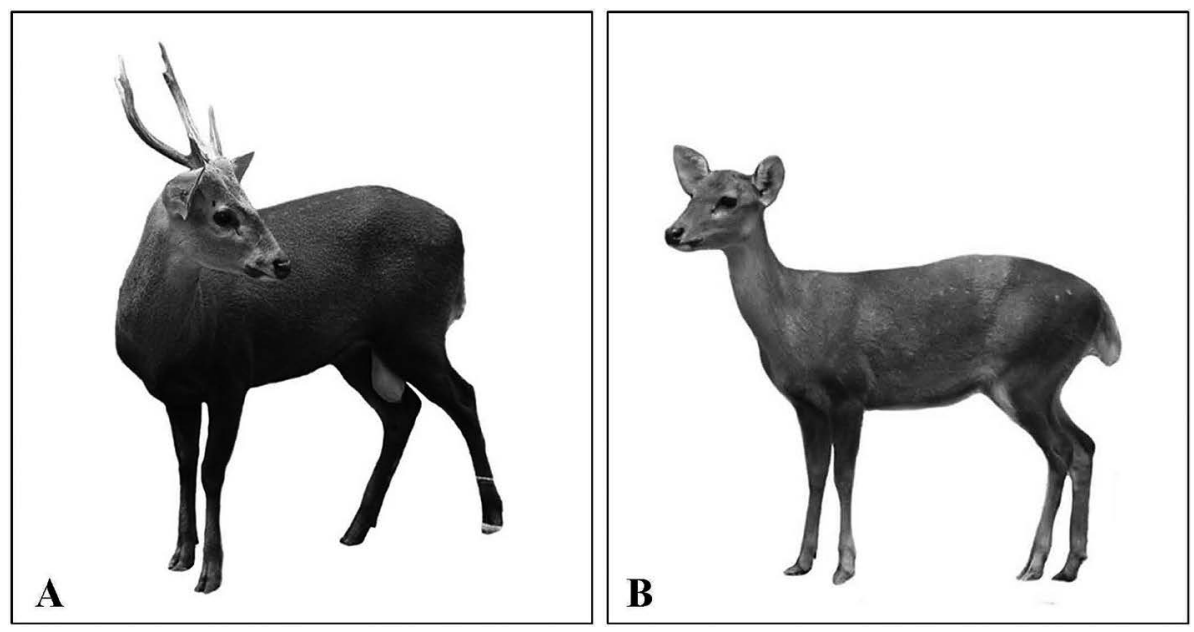

Fig. 1. General characteristics of male (A) and female (B) Indian hog deer (Hyelaphus porcinus).

Table 1. Mean length of short arm chromosome (Ls), long arm chromosome (L1), total arm chromosome (LT), relative length (RL), centromeric index (CI) and standard deviation (SD) of RL, CI from ten metaphases of male and female Indian hog deer (Hyelaphus porcinus) in Thailand, $2 n=68$.

\begin{tabular}{|c|c|c|c|c|c|c|c|}
\hline Chromosome pair & Ls & $\mathrm{L} 1$ & LT & $\mathrm{RL} \pm \mathrm{SD}$ & $\mathrm{CI} \pm \mathrm{SD}$ & Size & Type \\
\hline $1 *$ & 0.000 & 9.907 & 9.907 & $0.044 \pm 0.005$ & $1.000 \pm 0.000$ & Large & Telocentric \\
\hline $2 *$ & 0.000 & 8.785 & 8.785 & $0.039 \pm 0.002$ & $1.000 \pm 0.000$ & Large & Telocentric \\
\hline 3 & 0.000 & 8.527 & 8.527 & $0.038 \pm 0.003$ & $1.000 \pm 0.000$ & Large & Telocentric \\
\hline 4 & 0.000 & 8.450 & 8.450 & $0.038 \pm 0.002$ & $1.000 \pm 0.000$ & Medium & Telocentric \\
\hline 5 & 0.000 & 7.894 & 7.894 & $0.035 \pm 0.004$ & $1.000 \pm 0.000$ & Medium & Telocentric \\
\hline 6 & 0.000 & 7.782 & 7.782 & $0.035 \pm 0.001$ & $1.000 \pm 0.000$ & Medium & Telocentric \\
\hline 7 & 0.000 & 7.763 & 7.763 & $0.035 \pm 0.001$ & $1.000 \pm 0.000$ & Medium & Telocentric \\
\hline 8 & 0.000 & 7.520 & 7.520 & $0.033 \pm 0.005$ & $1.000 \pm 0.000$ & Medium & Telocentric \\
\hline 9 & 0.000 & 7.360 & 7.360 & $0.033 \pm 0.001$ & $1.000 \pm 0.000$ & Medium & Telocentric \\
\hline 10 & 0.000 & 7.217 & 7.217 & $0.032 \pm 0.001$ & $1.000 \pm 0.000$ & Medium & Telocentric \\
\hline 11 & 0.000 & 6.969 & 6.969 & $0.031 \pm 0.001$ & $1.000 \pm 0.000$ & Medium & Telocentric \\
\hline 12 & 0.000 & 6.824 & 6.824 & $0.030 \pm 0.001$ & $1.000 \pm 0.000$ & Medium & Telocentric \\
\hline 13 & 0.000 & 6.611 & 6.611 & $0.029 \pm 0.001$ & $1.000 \pm 0.000$ & Small & Telocentric \\
\hline 14 & 0.000 & 6.475 & 6.475 & $0.029 \pm 0.001$ & $1.000 \pm 0.000$ & Small & Telocentric \\
\hline 15 & 0.000 & 6.295 & 6.295 & $0.028 \pm 0.001$ & $1.000 \pm 0.000$ & Small & Telocentric \\
\hline 16 & 0.000 & 6.199 & 6.199 & $0.028 \pm 0.001$ & $1.000 \pm 0.000$ & Small & Telocentric \\
\hline 17 & 0.000 & 5.982 & 5.982 & $0.027 \pm 0.001$ & $1.000 \pm 0.000$ & Small & Telocentric \\
\hline 18 & 0.000 & 5.870 & 5.870 & $0.026 \pm 0.001$ & $1.000 \pm 0.000$ & Small & Telocentric \\
\hline 19 & 0.000 & 5.836 & 5.836 & $0.026 \pm 0.001$ & $1.000 \pm 0.000$ & Small & Telocentric \\
\hline 20 & 0.000 & 5.685 & 5.685 & $0.025 \pm 0.001$ & $1.000 \pm 0.000$ & Small & Telocentric \\
\hline 21 & 0.000 & 5.561 & 5.561 & $0.025 \pm 0.001$ & $1.000 \pm 0.000$ & Small & Telocentric \\
\hline 22 & 0.000 & 5.527 & 5.527 & $0.025 \pm 0.001$ & $1.000 \pm 0.000$ & Small & Telocentric \\
\hline 23 & 0.000 & 5.397 & 5.397 & $0.024 \pm 0.000$ & $1.000 \pm 0.000$ & Small & Telocentric \\
\hline 24 & 0.000 & 5.386 & 5.386 & $0.024 \pm 0.001$ & $1.000 \pm 0.000$ & Small & Telocentric \\
\hline 25 & 0.000 & 5.276 & 5.276 & $0.024 \pm 0.001$ & $1.000 \pm 0.000$ & Small & Telocentric \\
\hline 26 & 0.000 & 5.214 & 5.214 & $0.023 \pm 0.001$ & $1.000 \pm 0.000$ & Small & Telocentric \\
\hline 27 & 0.000 & 5.059 & 5.059 & $0.023 \pm 0.001$ & $1.000 \pm 0.000$ & Small & Telocentric \\
\hline 28 & 0.000 & 4.962 & 4.962 & $0.022 \pm 0.001$ & $1.000 \pm 0.000$ & Small & Telocentric \\
\hline 29 & 0.000 & 4.896 & 4.896 & $0.022 \pm 0.000$ & $1.000 \pm 0.000$ & Small & Telocentric \\
\hline 30 & 0.000 & 4.797 & 4.797 & $0.021 \pm 0.001$ & $1.000 \pm 0.000$ & Small & Telocentric \\
\hline 31 & 0.000 & 4.734 & 4.734 & $0.021 \pm 0.001$ & $1.000 \pm 0.000$ & Small & Telocentric \\
\hline 32 & 0.000 & 4.728 & 4.728 & $0.021 \pm 0.001$ & $1.000 \pm 0.000$ & Small & Telocentric \\
\hline 33 & 0.000 & 4.399 & 4.399 & $0.020 \pm 0.001$ & $1.000 \pm 0.000$ & Small & Telocentric \\
\hline$X$ & 4.584 & 5.268 & 9.852 & $0.044 \pm 0.003$ & $0.535 \pm 0.038$ & Large & Metacentric \\
\hline $\mathrm{Y}$ & 1.842 & 2.903 & 4.745 & $0.021 \pm 0.001$ & $0.612 \pm 0.028$ & Small & Submetacentric \\
\hline
\end{tabular}

Remark: *=Satellite chromosome (nucleolar organizer regions/NORs). 
of the tail is white and the deer can fan the white hairs out in a distinctive alarm display (Fig. 1). This species is listed on CITES appendix I and IUCN is Endangered
(Grzimek 2004, Groves 2006).

There are few cytogenetics reports of the H. porcinus as follows, Wurster and Benirschke (1967), Hsu and Be-
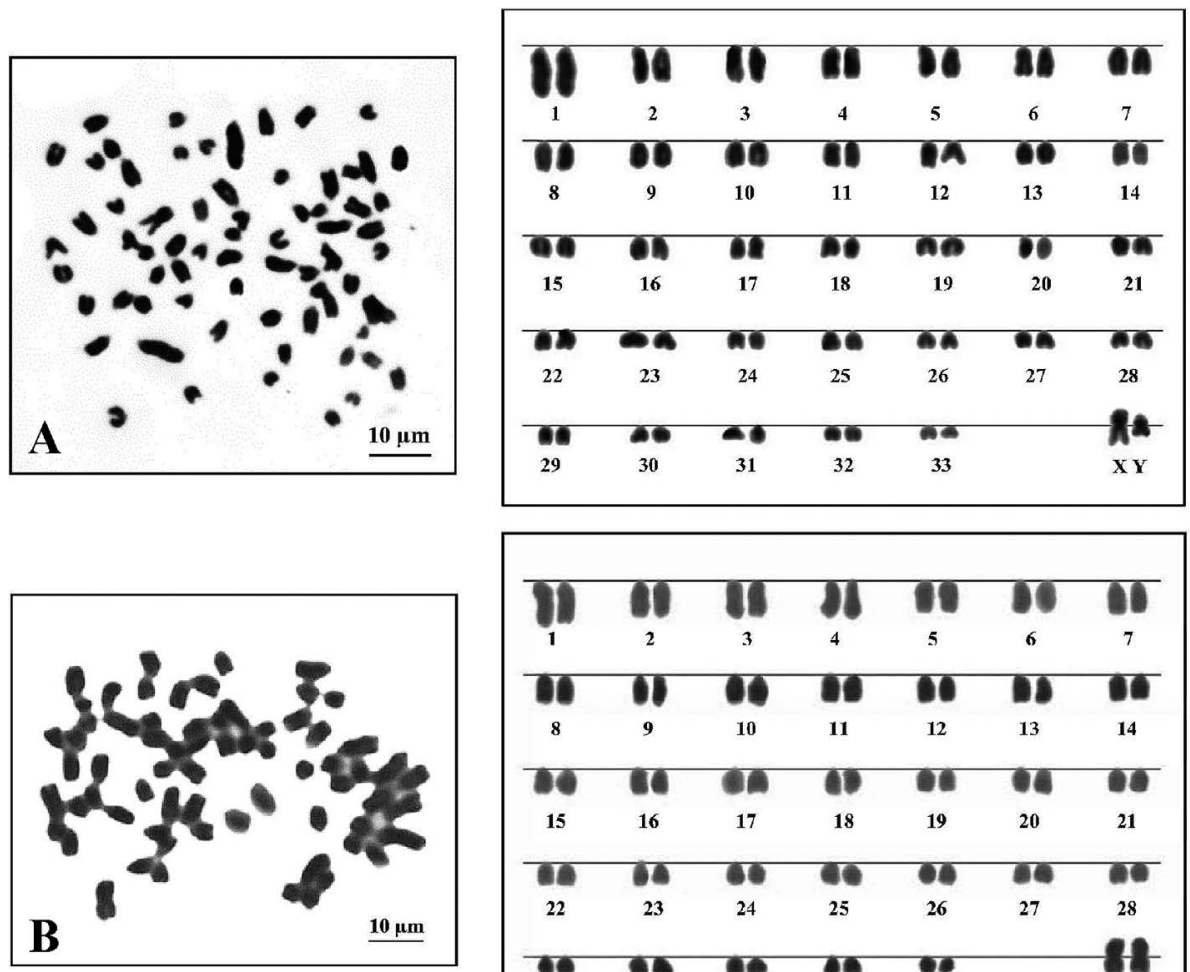

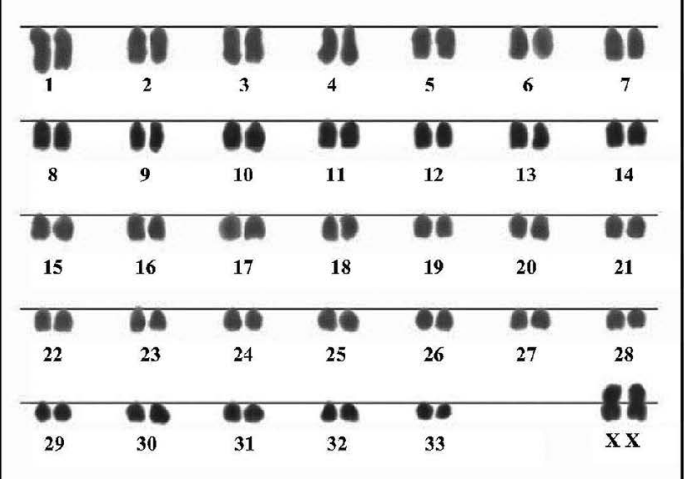

Fig. 2. Metaphase chromosome plates and karyotypes of male (A) and female (B) Indian hog deer (Hyelaphus porcinus), $2 n=68$ by conventional staining technique.
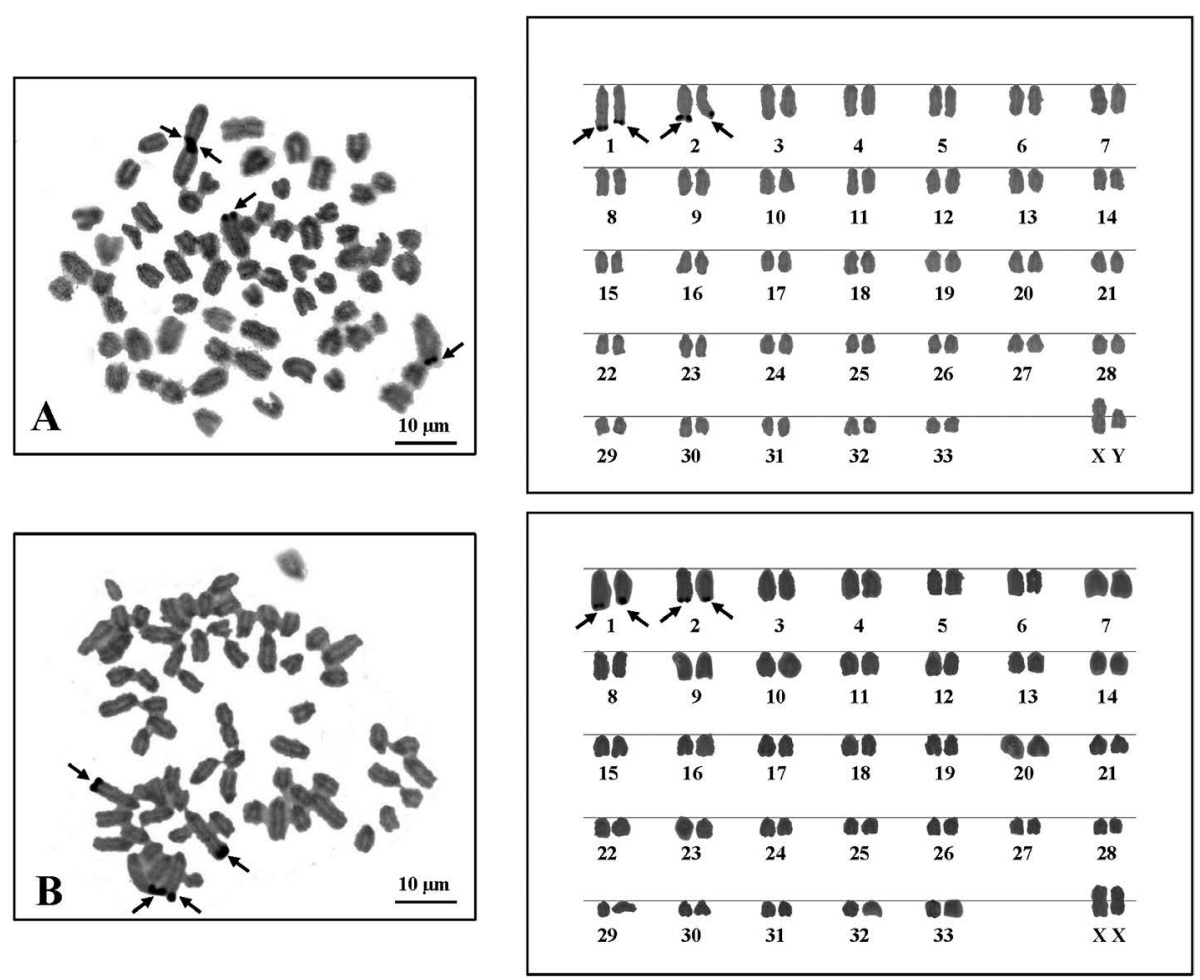

Fig. 3. Metaphase chromosome plates and karyotypes of male (A) and female (B) Indian hog deer (Hyelaphus porcinus), $2 n=68$ by Ag-NOR banding technique. Arrows indicate nucleolar organizer regions/NORs. 
nirschke (1977) and Chavananikul (1995) which report karyotypes of conventional staining of this animal. In our study, we confirm and compare our finding with previous reports. Moreover, this is the first report about standardized karyotype and idiogram measurements by GTG-, high-resolution and Ag-NOR banding techniques. This finding will represent basic knowledge and can be applicable to genetic diversity, taxonomy, conservation and evolution.

\section{Materials and methods}

Blood samples of the $H$. porcinus (two males and two females) were collected from Khon Kaen Zoo, Thailand and then applied to cytogenetic studies by lymphocyte culture of whole blood samples. The culture cells were treated with a colchicine-hypotonic-fixationair-drying technique followed by conventional staining, GTG-, high-resolution and Ag-NOR banding techniques (Rooney 2001, Campiranon 2003, Sangpakdee et al. 2017). For 20 cells of each individual chromosome, checks, length measurements, karyotype and idiogram analysis were accomplished by using a light microscope as previously described (Chooseangjaew et al. 2017).

\section{Results and discussion}

The cytogenetic study of $H$. porcinus using lymphocyte culture demonstrated that the chromosome number is $2 n$ (diploid) $=68$ and the fundamental number $(\mathrm{NF}$, number of chromosome arms) for both sexes is 70 (Table 1). These results agree with Wurster and Benirschke (1967), Hsu and Benirschke (1977) and Chavananikul (1995). The diploid number of Cervini species ranges from 56 to 68 with a constant fundamental number of 70. The decrease in chromosome number is due to an increase in the number of bi-armed chromosomes. Robertsonian fusions or translocations are described as the main rearrangement involved in this variation (BonnetGarnier et al. 2003, O’Brien et al. 2006).

The autosomes of $H$. porcinus consisted of 6 large telocentric, 18 medium telocentric and 42 small telocentric chromosomes. The $\mathrm{X}$ chromosome was large metacentric chromosome and $\mathrm{Y}$ chromosome was small submetacentric chromosome. Conventional, GTG-, highresolution and Ag-NOR banding karyotypes of $H$. porcinus demonstrate on Figs. 2-5, respectively. Moreover, the idiogram of those are illustrated on Figs. 6-9, respectively. These results disagree with Wurster and Benirschke (1967) and Hsu and Benirschke (1977) which reported that the autosomes of $H$. porcinus were two metacentric and 64 acrocentric (mono-armed), $\mathrm{X}$ was acrocentric and $\mathrm{Y}$ was acrocentric or submetacentric chromosomes. The sex chromosomes of $H$. porcinus in this study are like the sex chromosomes of some deer, Alces alces and Ca. capreolus (Gustavsson and Sundt 1968). The banding pattern of $H$. porcinus $\mathrm{X}$ chromosome is similar to human $\mathrm{X}$ chromosome. The

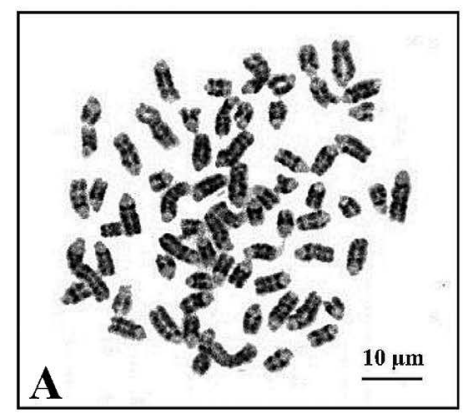

\begin{tabular}{|c|c|c|c|c|c|c|}
\hline \multicolumn{2}{|c|}{ dis 9} & 89 & 96 & $y$ & t6 & की \\
\hline 1 & 2 & 3 & 4 & 5 & 6 & 7 \\
\hline 97 & 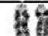 & 97 & Iี & 188 & צ8 & GE \\
\hline 8 & 9 & 10 & 11 & 12 & 13 & 14 \\
\hline 67 & 8 & 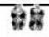 & म웅 & 86 & 96 & यद्व \\
\hline 15 & 16 & 17 & 18 & 19 & 20 & 21 \\
\hline k6 & Et & 훙혀 & प्रत्ष & 8 & ชิต & क्विल \\
\hline 22 & 23 & 24 & 25 & 26 & 27 & 28 \\
\hline 60 & $7 \sqrt{58}$ & 65 & मA & जी & & 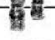 \\
\hline 29 & 30 & 31 & 32 & 33 & & $\mathbf{X Y}$ \\
\hline
\end{tabular}

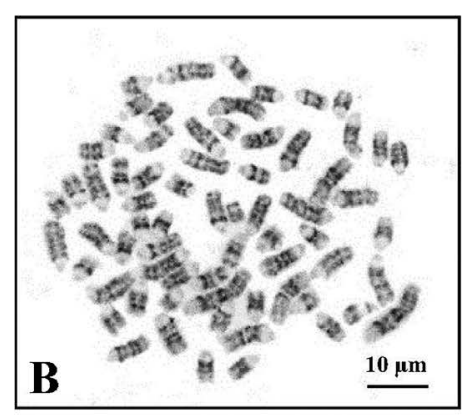

\begin{tabular}{|c|c|c|c|c|c|c|}
\hline 96 & -8 & $\sqrt{6}$ & ถิธ & 당 & 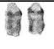 & ตE \\
\hline 1 & 2 & 3 & 4 & 5 & 6 & 7 \\
\hline 9.9 & $\sqrt{6}$ & 96 & 98 & 96 & 66 & 96 \\
\hline 8 & 9 & 10 & 11 & 12 & 13 & 14 \\
\hline 86 & 당ㅇㅂㅂ & dit & 68 & 96 & 다의 & 두요 \\
\hline 15 & 16 & 17 & 18 & 19 & 20 & 21 \\
\hline 80 & 8 & 69 & 86 & efe & बिक्ष & 86 \\
\hline 22 & 23 & 24 & 25 & 26 & 27 & 28 \\
\hline 96 & A & 86 & $\theta \theta$ & $\theta 6$ & & 86 \\
\hline 29 & 30 & 31 & 32 & 33 & & $\mathbf{x} \mathbf{x}$ \\
\hline
\end{tabular}

Fig. 4. Metaphase chromosome plates and karyotypes of male (A) and female (B) Indian hog deer (Hyelaphus porcinus), $2 n=68$ by GTG-banding technique. 


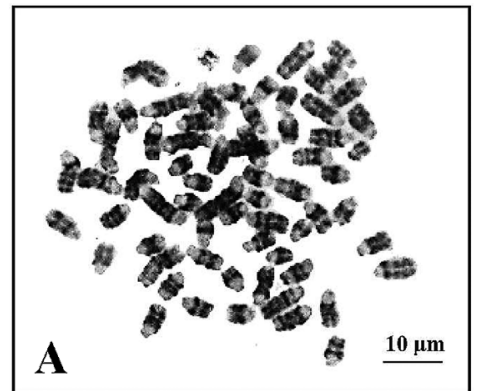

\begin{tabular}{|c|c|c|c|c|c|c|}
\hline 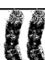 & 跑 & 85 & $y$ & 16 & 9 & $\mathrm{III}$ \\
\hline & 2 & 3 & 4 & 5 & 6 & 7 \\
\hline 7 & 6 & 밤 & 60 & (4) & व的 & 10 \\
\hline 8 & 9 & 10 & 11 & 12 & 13 & 14 \\
\hline 能 & 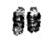 & 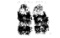 & 60 & 15 & ติติ & $0 A$ \\
\hline 15 & 16 & 17 & 18 & 19 & 20 & 21 \\
\hline 䧻 & fin & 69 & 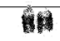 & 㧫 & 9 & 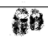 \\
\hline 22 & 23 & 24 & 25 & 26 & 27 & 28 \\
\hline $\mathbb{E}$ & 物 & 60 & राम & MA & & 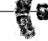 \\
\hline 29 & 30 & 31 & 32 & 33 & & $x y$ \\
\hline
\end{tabular}

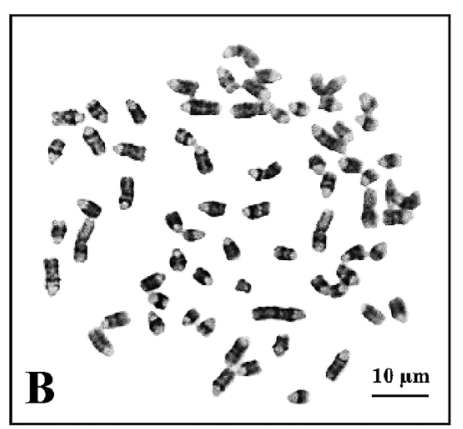

\begin{tabular}{|c|c|c|c|c|c|c|}
\hline 6 & 自 & 96 & 름 & 89 & 96: & 数 \\
\hline 1 & 2 & 3 & 4 & 5 & 6 & 7 \\
\hline 61 & $\frac{7}{9}$ & ํㅗำ & 59 & ติ & 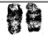 & ำ \\
\hline 8 & 9 & 10 & 11 & 12 & 13 & 14 \\
\hline की & 角结 & ติโี & 6 & 86 & 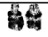 & कิषे \\
\hline 15 & 16 & 17 & 18 & 19 & 20 & 21 \\
\hline 68 & 붕함 & 96 & 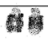 & 69 & ติ & CA \\
\hline 22 & 23 & 24 & 25 & 26 & 27 & 28 \\
\hline 96 & $6 n$ & 56 & 60 & an & & t. \\
\hline 29 & 30 & 31 & 32 & 33 & & $\mathrm{xx}$ \\
\hline
\end{tabular}

Fig. 5. Prometaphase chromosome plates and karyotypes of male (A) and female (B) Indian hog deer (Hyelaphus porcinus), $2 n=68$ by high-resolution GTG-banding technique.
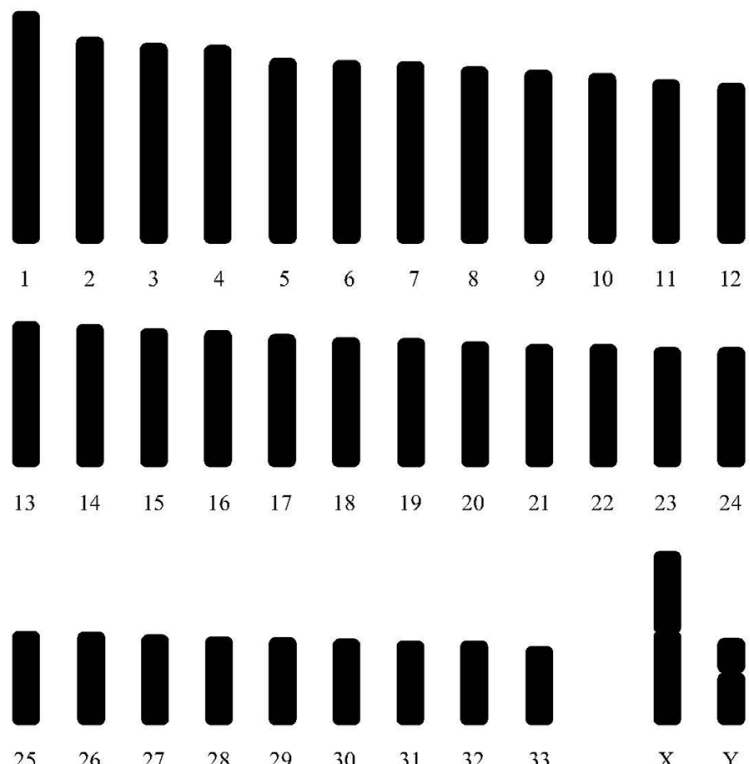

$31 \quad 32 \quad 33$

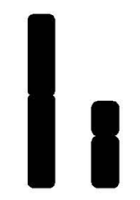

X Y

Fig. 6. Standardized idiogram of Indian hog deer (Hyelaphus porci$n u s), 2 n=68$ by conventional staining technique.

morphology of chromosome is different because of the classification of chromosome type in each system; previous studies used Levan et al. (1964) but this study used Turpin and Lejeune (1965) and Chaiyasut (1989).

The diploid chromosome number in deer varies greatly, but the causes of this variation are obscure. The NF in the tribe Cervini appears to be 70; the NF in New World deer is 74 . The actual $2 n$ is a function of chromo-
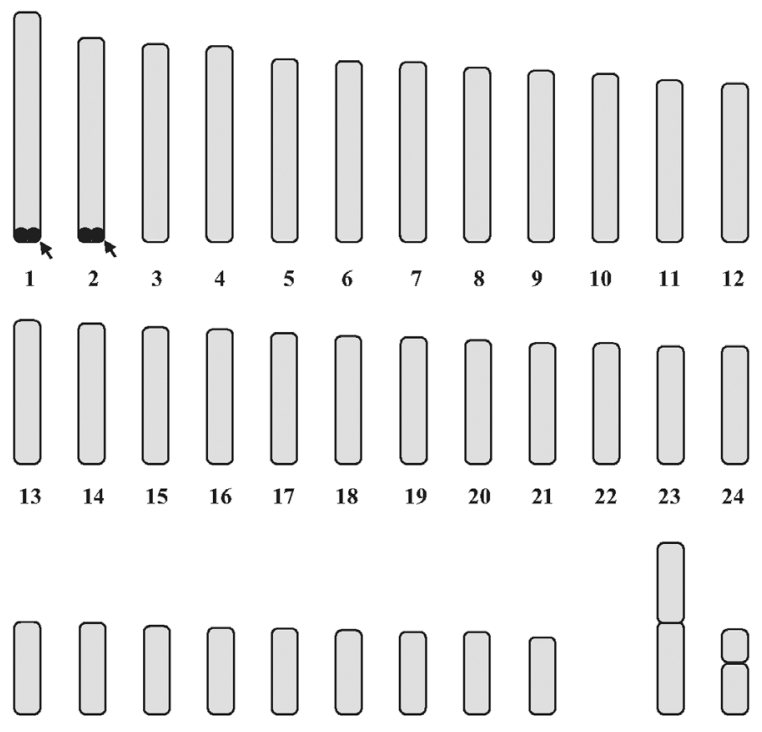

$\begin{array}{lllllllllll}25 & 26 & 27 & 28 & 29 & 30 & 31 & 32 & 33 & X & \text { Y }\end{array}$

Fig. 7. Standardized idiogram of Indian hog deer (Hyelaphus porci$n u s), 2 n=68$ by Ag-NOR banding technique, arrow indicates nucleolar organizer regions/NORs on the subtelomeric long arms of chromosome pairs 1 and 2 .

some fusions. New World deer differ from Old World deer by having metacentric or submetacentric $\mathrm{X}$ chromosomes (Geist 1998).

The first reported standardized idiogram of GTGbanding technique on $H$. porcinus show a pattern of transverse light and heavy bands; the amount of banding 


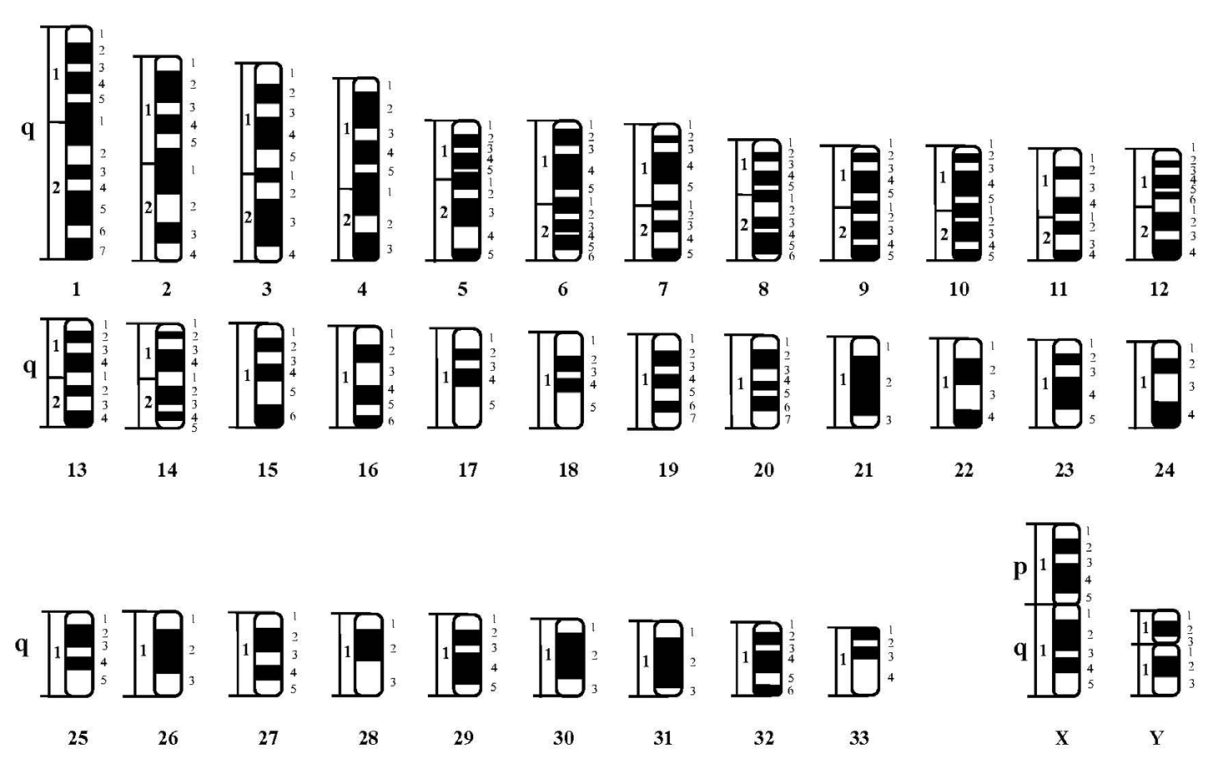

Fig. 8. Standardized idiogram of Indian hog deer (Hyelaphus porcinus), $2 n=68$ by GTG-banding technique.

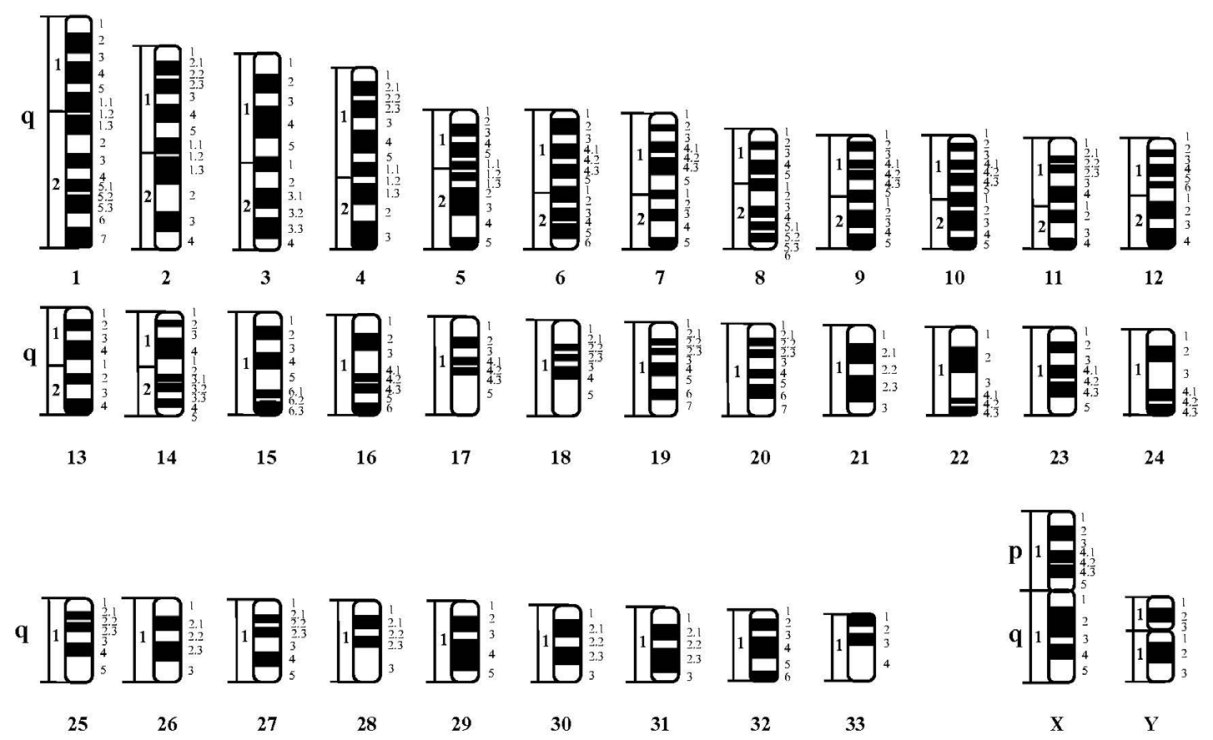

Fig. 9. Standardized idiogram of Indian hog deer (Hyelaphus porcinus) $2 n=68$ by high-resolution GTG-banding technique.

pattern on a set of haploid number $(n)$ including autosomes and sex-chromosomes is 240 and 300 bands on metaphase and prometaphase chromosomes, respectively. This result can be compared with Herzog (1987) and Bonnet et al. (2001) which reported the number of red deer (Ce. elaphus) and Vietnamese sika deer (Ce. nippon psuedaxis) banding pattern on metaphase chromosomes as 353 and 409 bands, respectively. This study showed a lower number of bands compared to previous studies because only clearly observable bands of the chromosomes were counted.

Ag-NOR banding showed clearly nucleolar organizer regions of $H$. porcinus located on the subtelomeric qarm of chromosome pairs 1 and 2. There are no heteromorphic NOR detection. This is a first report of NORs of this species. Numerous repetitive of $28 \mathrm{~S}$ and $18 \mathrm{~S}$ ribosomal gene are found in eukaryotic NORs. Multiplication of ribosomal DNA is able to increase or decrease size of NORs (Campiranon 2003). In conclusion, an asymmetrical karyotype is an important appearance of H. porcinus, in which three types of chromosomes consisting of metacentric, submetacentric and telocentric chromosomes were found. The karyotype formula for $H$. porcinus is as follows:

$2 n(68)=\mathrm{L}_{6}^{\mathrm{t}}+\mathrm{M}_{18}^{\mathrm{t}}+\mathrm{S}_{42}^{\mathrm{t}}+$ Sex-chromosomes.

\section{Acknowledgements}

This work was supported by the Toxic Substances in Livestock and Aquatic Animals Research Group, Khon Kaen University and we also thank the director of Khon Kaen Zoo for valuable help. Thanks are also expressed intended to the staff of this zoo for their good cooperation. 


\section{References}

Bonnet, A., Thevenon, S., Claro, F., Gautier, M. and Hayes, H. 2001. Cytogenetic comparison between Vietnamese sika deer and cattle: R-banded karyotypes and FISH mapping. Chromosome Res. 9: 673-687.

Bonnet-Garnier, A., Claro, F., Thevenon, S., Gautier, M. and Hayes, H. 2003. Identification by R-banding and FISH of chromosome arms involved in Robertsonian translocations in several deer species. Chromosome Res. 11: 649-663.

Campiranon, A. 2003. Cytogenetics. 2nd edition. Department of Genetics, Faculty of Science, Kasetsart University, Bangkok.

Chavananikul, V. 1995. Resemble and differences number of chromosome in some wildlife species in Thailand. Journal of Veterinary 28: 13-36. in Thailand

Chooseangjaew, S., Tanyaros, S., Maneechot, N., Buasriyot, P., Getlekha, N. and Tanomtong, A. 2017. Chromosomal characteristics of the tropical oyster, Crassostrea belcheri Sowerby, 1871 (Ostreoida, Ostreidae) by conventional and Ag-NOR banding techniques. Cytologia 82: 3-8.

Geist, V. 1998. Deer of the World: Their Evolution, Behaviour and Ecology. Stackpole Books, Mechanicsburg.

Groves, C. 2006. The genus Cervus in eastern Eurasia. Eur. J. Wildlife Res. 52: 14-22.

Grzimek, B. 2004. Grzimek's Animal Life Encyclopedia, Second Edition, Volume 15: Mammals IV. Thomson Gale, Detroit.

Gustavsson, I. and Sundt, C. O. 1968. Karyotypes in 5 species of deer (Alces alces L., Capreolus capreolus L., Cervus elaphus L., Cervus n. nippon Temm. and Dama dama L.). Hereditas 60: 233-248.

Herzog, S. 1987. Mechanisms of karyotype evolution in Cervus nippon Temminck. Caryologia 40: 347-353.

Hsu, T. C. and Benirschke, K. 1977. An Atlas of Mammalian Chromosomes Vol. 10. Springer-Verlag, New York.

Huang, L., Nie, W., Wang, J., Su, W. and Yang, F. 2005. Phylogenomic study of the subfamily Caprinae by cross-species chromosome painting with Chinese muntjac paints. Chromosome Res. 13: 389-399.

Khongcharoensuk, H., Tanomtong, A., Patawang, I., Supanuam, P.,
Somnok, S. and Pinthong, K. 2017. Karyotype and idiogram of the axis deer (Axia axis, Cervidae) by conventional staining, GTG-, high-resolution GTG-, and Ag-NOR-banding techniques. Cytologia 82: 91-98.

Levan, A., Fredga, K. and Sandberg, A. A. 1964. Nomenclature for centromeric position on chromosome. Heriditas 2: 201-220.

Meijaard, E. and Groves, C. P. 2004. Morphometrical relationships between South-east Asian deer (Cervidae, tribe Cervini): Evolutionary and biogeographic implications. J. Zool. 263: 179-196.

Neitzel, H. 1987. Chromosome evolution of Cervidae: Karyotypic and molecular aspects. In: Obe, G. and Basler, A. (eds.). Cytogenetics-Basic and Applied Aspects. Springer-Verlag, Berlin. pp. 90-112.

O'Brien, S. J., Menninger, J. C. and Nash, W. G. 2006. Atlas of Mammalian Chromosomes. John Wiley and Sons, Inc., New York.

Pitra, C., Fickel, J., Meijaard, E. and Groves, C. P. 2004. Evolution and phylogeny of old world deer. Mol. Phylogenet. Evol. 33: 880-895.

Rooney, D. E. 2001. Human cytogenetics: constitutional analysis. Oxford University Press, Oxford.

Sangpakdee, W., Phimphan, S., Tengjaroenkul, B., Pinthong, K., Neeratanaphan, L. and Tanomtong, A. 2017. Cytogenetic study of tree microhylid species (Anura, Microhylidae) from Thailand. Cytologia 82: 67-74.

Tanomtong, A., Chaveerach, A., Phanjun, G., Kaensa, W. and Khunsook, S. 2005. New records of chromosomal features in Indian muntjacs (Muntiacus muntjak) and Fea's muntjacs (M. feae) of Thailand. Cytologia 70: 71-77.

Tanomtong, A., Jearranaiprepame, P. and Supiwong, W. 2010. A new polymorphism of nucleolar organizer regions (NORs) of Indian muntjac (Muntiacus muntjak) in Laos PDR. Cytologia 75: 23-30.

Turpin, R. and Lejeune, J. 1965. Les Chromosomes Humains (Caryotype Normal et Variations Pathologiques). Gauthier-Villars, Paris.

Wurster, D. H. and Benirschke, K. 1967. The chromosomes of 23 species of Cervidae and Bovidae. Mamm. Chromosomes Newsl. 8: 226.

Wurster, D. H. and Benirschke, K. 1970. Indian muntjac, Muntiacus muntjak: a deer with a low diploid chromosome number. Science 168: 1364-1366. 